\title{
Universal Chronicles in the Early Medieval West
}

\section{Ian Wood*}

Abstract: This paper considers the modern concept of a suniversal chronicle<, examining its validity for Latin texts written before the mid-ninth century. It notes that while modern historians of Late Antiquity and the Early Middle Ages concentrate on the most recent material in chronicles and other historical writings, the original authors were usually concerned to set events of their own day within a framework that began with the Creation, the Birth of Adam, or of Abraham, and that as a result most historical texts should be seen primarily as tracing the history of Salvation. As such they need to be understood as one manifestation of a more general concern with the nature of Time.

Keywords: chronicle, Bede, Isidore, Fredegar

The phrase universal chronicle, chronicon universale, does not constitute a category that was identified as such in late antique or early medieval sources - a point that also holds true for the early Islamic World. Its application to historical writings of the late- and post-Roman periods would appear to be an innovation of the nineteenth century. As a category it may have something to commend it for modern scholars seeking a shorthand to define a rather disparate selection of works - as long as one understands it only to be a shorthand. Certainly, the definition and categorisation of historical texts can be useful, and indeed there are numerous basic types. Among them one may point to chronicles as being concerned primarily with chronology and the marking of time. ${ }^{1}$ Yet so too are other records, including lists of rulers and office holders, known now as fasti and consularia (again modern terms), ${ }^{2}$ as well as episcopal lists, and even tables intended for the calculation of the date of Easter (which sometimes attracted historical annotations). ${ }^{3}$

All these other types of record were distinguished by the brevity of their entries, and as such they were similar to chronicles, which Cassiodorus defined as ssnapshots of history or very brief summaries of the past (imagines historiarum brevissimae commemorationes temporum $){ }^{4}$ The term chronicon, however, is by no means the only one used in the Early Middle Ages to describe short historical texts. Thus Isidore described his own chronicle, which Mommsen edited under the title Chronica Maiora, as a ssumma temporum ab exordio mundi usque ad Augusti Heraclii vel Sisebuti regis principatum‘, which continued the sbrevem temporum` of Julius Africanus, the schronicorum canonum multiplicem ... historiam` of Euse-

* Correspondence details: Professor Ian N. Wood, Institute for Medieval Studies, University of Leeds, Leeds LS2 9JT, U.K., email: i.n.wood@leeds.ac.uk

1 Burgess and Kulikowski, Mosaics of Time, 22.

2 Burgess and Kulikowski, Mosaics of Time, , 10-12, 133.

3 Burgess and Kulikowski, Mosaics of Time, 1-5.

4 Cassiodorus, Institutiones divinarum et saecularium litterarum, I, 17, 2, ed., Mynors, trans. Halporn and Vessey, 150; Burgess and Kulikowski, Mosaics of Time,, 25. 
bius and Jerome, and the sgesta sequentium aetatum description of his sources we find that a group of texts that we would see as belonging to the same category could be described as chronological summaries (summae, breves temporum), a many-sided history of the canons of chronicles (multiplex historia chronicorum canonum), and as deeds of sequential years (gesta sequentium annorum).

Just as a single form might be described in a variety of ways, so too different forms might be combined to create a single text. The Chronicle of Cassiodorus has been seen as a combination of two different genres, consular fasti and the chronicle. ${ }^{6}$ But, equally, examples of several types of text might be preserved alongside each other in a single collection. Thus the so-called Chronography of 354, a compendium of texts put together by Filocalus, included a list of consuls, an Easter cycle (providing a calendar of the days on which Easter was to be celebrated), lists of the City Prefects, of the burials of bishops and martyrs, and of the bishops of Rome, a description of the imperial city, the Liber Generationis of Hippolytus (a very brief narrative of events from the creation of Adam, starting with the words Liber Generationis hominum), which was augmented and extended down to 334, and a Chronica Urbis Romae. ${ }^{7}$ The inclusion of the Liber Generationis, together with the Roman Chronicle, alongside a collection of lists of office holders and of figures to be commemorated, as well as an Easter cycle, which was based on an earlier computistical work, also by Hippolytus, is a powerful reminder that historical writing could be categorised along with non-narrative works that were also concerned with the question of time and commemoration.

Filocalus was by no means the last to make such a compilation. In the mid seventh century the chronicler known as Fredegar put together a collection of chronographic material, including texts written in the third and fourth centuries. This begins with a version of the Liber Generationis of Hippolytus (augmented with information from, among other sources, a history of Troy), to which are added a chronological computation drawn from Eusebius/Jerome, running from Adam to the Frankish king Sigibert II (613), a list of popes, Isidore's account of the Creation of the World, a list of patriarchs, kings and emperors down to Heraclius, followed by extracts from Eusebius/Jerome, and Hydatius, before providing an epitome of Books I-VI of the Histories of Gregory of Tours and Fredegar's own chronicle. ${ }^{8}$ Not that Fredegar, himself, appears to have used the term >chronicle`, although later redactors talk of his work as including a cronece Gyromini scarpsum ${ }^{9}$ and a scarpsum de cronica Gregorii. ${ }^{10}$ Moreover, in the prologue to Fredegar's own contribution, usually known as Book Four, the author announces that he has read the Chronicles of Jerome, Hydatius, sa certain wise man<, Isidore and Gregory, from the beginning of the World (beati Hieronimi, Ydacii et cuiusdam sapientis, seo Hysidori immo et Gregorii chronicis a mundi originem diligentissime percurrens) and that he has inserted slightly abbreviated versions of all five of them into his libellus. ${ }^{11}$ One might add that his own additions are set out in the annalistic format associated with the chronicle genre, even if the individual entries are rather more substantial than one would expect of a type of history known for its brevity.

5 Isidore, Chronica Maiora, 1-2, ed. Mommsen, 424-425.

6 Burgess and Kulikowski, Mosaics of Time, 41-42.

7 Salzman, On Roman Time, 35-56.

8 Wallace-Hadrill, The Fourth Book of the Chronicle of Fredegar, x-xi: Collins, Die Fredegar-Chroniken, 56-59.

9 Fredegar, ed. Krusch, 42.

10 Fredegar, ed. Krusch, 89.

11 Fredegar, IV, prol., ed. Krusch, 123. 
Although Fredegar himself does acknowledge that the opening of his work is made up of lists, implying that the subsequent historical narrative, which is what attracts the modern scholar, is of less importance than what comes before, he presents the opening section of his compilation (or what would later be known as Book One) as very much more biblically inspired than the above summary would suggest: ${ }^{12}$

The book of descent (liber generationis) from Adam in order, which is contained in this volume of a book (volumen libri). The listing (denumeratio) of times and years. The descent of the world down to the present. The division of the earth by the three sons of Noah. A statement (declaratio) of the people who were created out of them, and which lands and cities fell to the lot of each. The number of notable islands. Which of each of the peoples migrated. The names of rivers. What the mountains are called. The judges, who judged the people for years. Which kings reigned over the tribe of Judah, and who reigned in which years. A statement of Easter (declaratio Paschae), and who ruled from the time of Moses until the present. The emperors of the Romans, from Augustus, and who reigned in which years. The time of Olympiads from Ipitus to the present Olympiad. The names of the patriarchs by descent. The names of the prophets. The women prophetesses. The names of the kings of the Hebrews, and of the kings who ruled in Samaria over the ten tribes, and who ruled in which years. The names of priests. The names of the emperors of Rome, and who ruled in which years.

Since a man ought to know the truth, I have reckoned it necessary, dearest brother, to set these words (sermones) out in short (in breve) from the holy scriptures, to corroborate doctrine, so that through small pieces of narration (per paucas enarrationis) we might learn more quickly not without reason the sought-out virtues of truth, cutting out the arguments generated earlier by the unlearned, which obscure the sense, so that it might teach the unlearned in this way. Desiring to see the summary (summa) industriously, we learn according to truth the division of the peoples and the listed descent of their ancestors, their dwelling places, and the times of wars fought and the times of the dispensation of the judges, and the years of kings and the times of prophets, and who was born to which kings, and how the captive peoples related to kings and judges, and which judges were present at which times, and what division and what loss took place, and in what way the descent of the seed of Israel from the patriarchs was fulfilled in Christ, and how many years are listed in what times, from the creation of the World to the present. We intend, however, beginning in Genesis, following the Revelation of the Word, to narrate as it happened, not as it is proved on our part, but from the Holy Scriptures themselves. Picking up on this line we set out our account (sermo) in the order of Genesis.

Fredegar is not usually considered alongside Filocalus, because scholars tend to ignore the opening sections of his compilation. One might also wonder whether the ninth-century Historia Brittonum, which in one manuscript is described as ra heap of all that I have found, both from the Annals of the Romans and from the Chronicles of the Holy Fathers, and from the writings of the Irish and the English, and out of the traditions of our elders $<,{ }^{13}$ can usefully be considered as having something in common with both Filocalus and Fredegar. Although the Historia has convincingly been presented as being written in Gwynedd, in c. 829, and as deliberately responding to Bede's Historia Ecclesiastica, ${ }^{14}$ its format, which echoes the

12 Fredegar, praef., ed Krusch, 19-20.

13 Historia Brittonum, praef., ed. Morris, 9, 50.

14 Higham, King Arthur, 119-24. 
description in the preface, and which includes a brief account of Biblical History, followed by a description of the Six Ages of the World, points rather to the concept of history that seems to have been envisaged by Fredegar.

If we talk about a category not just of chronicles, but specifically of universal chronicles, we are dealing even more obviously with modern rather than ancient categorisation: the phrase chronicon universale is not, to my knowledge, used in Late Antiquity or the Early Middle Ages. However, in talking about his translation and extension of Eusebius' Chronicle Jerome says that rquae universa in suis locis cum summa brevitate ponemus (sall of this I have placed in its correct context with utmost brevity $).{ }^{15}$

It is, of course, possible to justify the term suniversal<. The Eusebius/Jerome Chronicle begins with the birth of Abraham. Other chroniclers begin with the creation of the World or of Adam (as does Hippolytus, and indeed Fredegar - as well as such Islamic historians as Ibn Habib). The choice of the precise moment at which a narrative begins was significant, in that it impinges on the question of the age of the world, which could be regarded as important, if one thought that it would only last 6000 years: to place Christ's birth 5500 years after the Creation, as many did, following Julius Africanus, might imply that the world would end in $500 \mathrm{AD} \cdot{ }^{16}$ Eusebius deliberately began with Abraham's birth, on the grounds that one could not compute the number of years that had passed before that date. Not everyone agreed with him, with the result that different chroniclers opted for different dates as the start of their chronological computations. ${ }^{17}$ In terms of defining certain historical texts as universal the precise moment at which a text begins is of less importance. Clearly a chronicle that begins with the Creation of the World, of Adam, or the birth of Abraham, can be regarded as universal, in that it initially deals with the totality of the created world, but so too can a chronicle that combines biblical and non-biblical, and especially Greek and Roman, narratives, in that this constitutes a coverage of much of the history available.

The origins of the Christian tradition of providing a summary of events in the history of the World, are usually traced to Julius Africanus, who in c.221 AD attempted to synchronise Hebrew and Greek History. ${ }^{18}$ This work was continued a generation later in the Liber Generationis attributed to Hippolytus of Rome (the text later used at the beginning of the Fredegar compilation). ${ }^{19}$ This in turn was developed by Eusebius in his Chronici Canones, which in Jerome's translation and continuation, down to the year 379, can reasonably be taken as the starting point of a Western chronicle tradition. ${ }^{20}$ The Eusebius/Jerome Chronicle most certainly attempts to be universal, synchronising the entries for each historical tradition in parallel columns. Thus one has parallel entries for anything up to nine peoples, including the Assyrians, the Hebrews, the Greeks, the Latins and the Egyptians. ${ }^{21}$ As one nation is subjected to another, so its column vanishes, until history is reduced to two columns, the Roman and the Jewish, and then, with the conquest of Jerusalem, to a single one. Thus, both the narrative and its visual representation on the page mark the steady rise of Rome to world dominance - and coinciding with the triumph of Rome was the Incarnation of Christ.

15 Hieronymus, Chronicon, pref., ed. Helm, 19; Burgess and Kulikowski, Mosaics of Time, 26.

16 Whitby, The Biblical Past in John Malalas, 282.

17 Whitby, The Biblical Past in John Malalas, 283-284.

18 Whitby, The Biblical Past in John Malalas, 282; Burgess and Kulikowski, Mosaics of Time, 116.

19 Whitby, The Biblical Past in John Malalas, 282; Burgess and Kulikowski, Mosaics of Time, 117-118.

20 Burgess and Kulikowski, Mosaics of Time, 123-129.

21 Whitby, The Biblical Past in John Malalas, 282. 
The majority of the chronicles written in western Europe in the Early Middle Ages are continuations of the chronicle or of epitomes of Eusebius/Jerome. Thus Prosper of Aquitaine continued Jerome's work from 379 , initially down to 445 , and subsequently to $455 ; ;^{22}$ another Gallic chronicle runs to a date usually computed as $452 ;{ }^{23}$ Hydatius added annals to Jerome down to $469 .{ }^{24}$ In 518 count Marcellinus provided another extension of Eusebius/Jerome. ${ }^{25}$ Later generations added to these initial continuations. Thus Marius of Avenches probably continued Prosper's Chronicle, taking events down to 581, although in the sole surviving manuscript of Marius' work most of Prosper's text is replaced by that of the Chronicle of $452 .{ }^{26}$ So too Victor of Tunnuna expanded Prosper's work down to 565, and his chronicle in turn was continued with annals to 589 by John of Biclar, while a much later Spanish chronicle, that of 741 (which is often referred to as the Chronicon Universale, albeit with no justification from the manuscript) follows John. ${ }^{27}$ Isidore of Seville created an epitome out of the chain of chronicles running from Jerome, to Victor and John, adding his own entries down to $626{ }^{28}$

Although all of these chronicles have been edited, in several cases the editions are misleading in that individual continuations have been published as free-standing texts, without the preceding chronicles to which they are attached. ${ }^{29}$ Each complete chain of chronicles, however, should be seen as a universal chronicle in its own right. Not only are the interests of the continuators to be found in the choice of material to be included in their continuations: at times they also transformed what was before them. This is clear when one looks at the alterations made to the text of Eusebius/Jerome, most obviously with regard to the dating systems used: Jerome's dating from Abraham and his use of Olympiads, regnal and imperial dates was modified, and the Spanish era, consular dating, and indictions were used in addition or instead..$^{30}$ Moreover, to judge by manuscript variations, earlier annals in the chain of texts were sometimes deliberately edited: for instance, the regnal dates of Frankish kings are inserted into Jerome's text in the Munich and Bamberg manuscripts that contain both Eusebius/Jerome and the Chronicle of $452 .{ }^{31}$ As a result the kingdom of the Franks is treated in the same way as the kingdoms which attracted the attention of Eusebius and Jerome, who, of course, take us right back to biblical tradition. In addition, not only does each continuation constitute a different chronicle, but so too does each manuscript. The Chronicle of 452 is preserved in three different chains of chronicles, and each chain can be understood as a unique compilation..$^{32}$ The vitality of the western chronicle tradition has to be understood not only from the composition of new chronicle texts, and the addition of annalistic entries, but also from the manuscript transcriptions.

23 Wood, Chains of Chronicles; Burgess and Kulikowski, Mosaics of Time, 185.

24 Burgess and Kulikowski, Mosaics of Time, 185.

25 Burgess and Kulikowski, Mosaics of Time, 185.

26 Wood, Chains of Chronicles, 70; Burgess and Kulikowski, Mosaics of Time, 186.

27 Burgess and Kulikowski, Mosaics of Time, 187, 202.

28 Burgess and Kulikowski, Mosaics of Time, 187.

29 Wood, Chains of Chronicles, 68; Burgess and Kulikowski, Mosaics of Time, 40

30 Jerome dates from the Birth of Abraham, using Olympiads, regnal and imperial dates; Hydatius adds the Spanish era; Prosper uses consular dating; count Marcellinus use consular dating and indictions. On the changes to dating see Burgess and Kulikowski, Mosaics of Time, 129, 185.

31 Wood, Chains of Chronicles, 73.

32 Wood, Chains of Chronicles, 68. 
Taken out of context the continuations of such authors as Hydatius, the 452 chronicler, and Marius, do not look universal, because their own additions tend to becoming increasingly local. In part the growing localism reflects the difficulties of communication occasioned by the disruptions of the fifth century. This is especially true of Hydatius, based in the far north-west of Spain. ${ }^{33}$ Yet the reduction in the horizons of the compilers should not be seen as marking an abandonment of universal history. Hydatius' concerns remained broad: they were, however, universal not in a geographical sense, but rather in the sense that they were focussed on the End of the World, which he thought was imminent. ${ }^{34}$ Not all the continuators of Eusebius/Jerome had such an eschatological message (despite the possible imminence of the End of the World), although they were all concerned with far more than the simple record of events. ${ }^{35}$

A chronicle taking as its point of departure the Creation, the Birth of Adam or the Birth of Abraham is, in a way, almost automatically a work of providential history, mapping the progress of the world, through to the moment of the Birth of Christ, which, of course, is given particular emphasis in Eusebius/Jerome manuscripts. ${ }^{36}$ Not all providential histories, however, look like the Chronici canones of Eusebius/Jerome: there are texts categorised as Historiae and not Chronica - that is, texts which do not follow the annalistic format of Eusebius/Jerome, but rather offer an extended narrative in a more classical tradition. ${ }^{37}$

Orosius' History against the Pagans can certainly be placed within a tradition of Roman historical, rather than chronicle, writing. ${ }^{38}$ Yet its religious purpose is clear from the preface addressed to Augustine, who, Orosius reveals, had instructed him to write against the pagans. The history is, therefore, to be religious history, and although he begins by talking of Ninus, the first king of the Assyrians, his point of departure is essentially the same as that of Eusebius/Jerome, since Ninus was supposedly the ruler at the time of Abraham. ${ }^{39}$ Orosius states the length of time between Adam and Abraham, but notes that nothing is known about the period. Thereafter he writes that there were 2015 years from Ninus and Abraham to Christ, and then announces that divine providence rules the world and men. Before embarking on the historical narrative, however, he provides a geographical survey as an introduction to what follows. ${ }^{40}$ Although its format differs radically from that to be found in the Eusebian tradition, this is providential history, and, at least in its opening stages, universal history, for the geography covers the whole of the known world, and the historical narrative takes in the Old Testament, Greek legend, including the Trojan War, as well as Greek and Macedonian history, before focussing on Rome and the growth of its empire. Orosius' History would have a profound impact on subsequent historical writing.

33 Burgess, Hydatius and the Final Frontier, 321.

34 Burgess, Hydatius and the Final Frontier.

35 Muhlberger, The Fifth-Century Chroniclers, 193-226; Wood, The End of Roman Britain, 19; Wood, Chains of Chronicles, 71-72.

36 Hieronymus, Chronicon, ed., Helm 1956, 169. The typographical layout of the edition reflects the emphases in many of the manuscripts.

37 Van Nuffelen, Orosius and the Rhetoric of History.

38 Van Nuffelen, Orosius and the Rhetoric of History.

39 Orosius, Historia Adversus Paganos, I, 1, trans. Fear, 33-34

40 Orosius, Historia adversus Paganos, I, 2, trans. Fear, 36. On the geography Lozovsky, »The Earth is our Book«, 6978; Merrills, History and Geography, 35-99. 
Gregory of Tours, for instance, in his preface to the first book of his Histories, having provided his own statement of faith, announces that he is following in the footsteps of Eusebius/ Jerome, Orosius and Victorius of Aquitaine.$^{41} \mathrm{He}$ ignores, therefore, any distinction between what might be called the chronicle and historical traditions, and this approach can be clearly seen in Book Two of the Histories, which seems to contain annal entries within a more expansive narration. ${ }^{42}$ Gregory begins his narrative with Adam, in order, so he states, sthat the sequence of time may be properly understood.${ }^{43}$ There follows a very short summary of major events in the Old Testament, a longer narration of the life of Christ, before the narrative follows the early persecutions and the establishment of the Church in Gaul. Thereafter Gregory's focus is almost entirely on Gaul and Francia, to the extent that his work came to be regarded wrongly as a >History of the Franks $\triangleleft{ }^{44}$ Although such a reading was already current by the end of the seventh century, it is clear that one should accept Gregory's own assessment of his work: he wrote >Histories`, and not the >History` of a particular group. Despite its geographical focus, the work begins as universal history, and it continues to be concerned with the workings of the divine, even though Gregory increasingly focuses on events in Francia, and was himself bewildered by what he observed.

Among the authors who drew on Gregory we have already noted Fredegar, whose mid-seventh-century compilation, at least in its initial sections, looks back to earlier chronographic work, culminating in Eusebius/Jerome, before excerpting the work of the Bishop of Tours, which later Fredegar manuscripts, as we have seen, describe as Cronica. Perhaps surprisingly, given the supposed cultural, economic and political weaknesses of the seventh century, Fredegar's horizons seem to be broader than those of Gregory, and not only in his inclusion of lists of popes down to Theodore (642) and emperors down to Heraclius. His narrative also has an eye on events in the East, as well as in the Slav world: it thus seems that it should be understood not as a work of Frankish, but of suniversal history. But while Fredegar's breadth of interest is clear, his interpretative scheme is less so, perhaps because the work is incomplete. His political opinions are obvious enough, but, despite his preface, his overall interpretation of history is harder to fathom. ${ }^{45}$ However, as the preface makes clear, whatever understanding of history he had, it took as its starting point the Old Testament. ${ }^{46}$

Arguably there is little that is universal in the work the next of the Frankish historians, where we can genuinely talk of a concentration on Frankish history, although at the same time we can still observe a spiritual framework. The author of the Liber Historiae Francorum, writing in the region of Soissons in c.727, announces at the start that 'we are setting out the beginnings of the kings of the Franks, and their peoples, and their origins and deeds، (Principium regum Francorum eorumque origine vel gentium illarum ac gesta proferamus) ${ }^{47}$ This origin-story begins in the Asian city of Troy. When the tyrant Aeneas fled to Italy, Priam, Antenor and the rest of the Trojan army set off for the Maeotic marshes, and founded the city of Sicambria, where they emerged as Franks. ${ }^{48}$ This clearly is national, and thus not universal,

41 Gregory of Tours, Historiae, I, praef., ed Krusch, 3-5.

42 e. g. Gregory of Tours, Historiae, II 18, ed. Krusch, 65.

43 Gregory of Tours, Historiae, praef., ed. Krusch, 1, trans. Thorpe, 63.

44 Goffart, From Historiae to Historia Francorum; Goffart, The Narrators of Barbarian History, 119-127.

45 Wood, Fredegar's Fables.

46 Fredegar, praef., ed Krusch, 19-20.

47 Liber Historiae Francorum, 1, ed. Krusch, 241.

48 Liber Historiae Francorum, 1, ed. Krusch, 241.

medieval worlds • No. 1 • $2015 \cdot 47-60$ 
history. And yet careful analysis of the text reveals that the author was deeply influenced by the Bible, and indeed that he was presenting the Franks as a counterpart to the Children of Israel. As a result even this text can be read (as can numerous works of Christian historiography) as ssalvific history ${ }^{49}{ }^{49}$

Although the notion of >National Histories of the Germanic Peoples` has rightly been called into question by Walter Goffart, ${ }^{50}$ it is clear that some authors were concerned with the history of individual peoples. Gregory of Tours does not announce that he is writing about the Franks, but the author of the Liber Historiae Francorum does. So too Jordanes writes both Roman and Gothic histories, and Paul the Deacon imitates him in writing Roman and Lombard histories. One might read the Romana and the Getica of Jordanes together as a pair, and thus see them as encompassing two peoples rather than one - and since he temporarily broke off writing the former in order to write the latter this is not an unreasonable way of considering the two works. The Romana begins with an abridged version of Eusebius/Jerome, running from Adam to Augustus: thereafter it integrates the historical writings of Florus, Orosius and count Marcellinus, among others, to bring its concise narrative down to the wars of Justinian..$^{51}$ What begins as universal providential history becomes something much more geographically specific. The Getica, by contrast, does not repeat the early history of the world, but begins, explicitly in the manner of Orosius, with geography: after a listing of the continents of Asia, Africa and Europe, Jordanes gives brief consideration to the Mediterranean and of the Ocean, before turning to Scandinavia, which serves as a point of departure for the migrating Goths..$^{52}$ More obviously than the Romana, the Getica has as its ultimate focus the reign of Justinian, and the hope that the union of Goth and Roman, marked by the marriage of Matasuntha and Germanus, will lead to a new dawn for the Ostrogothic people..$^{53}$ Jordanes' prime concern would seem to be the political situation of his own day, rather than any broader spiritual message.

While Paul the Deacon may have intended his Historia Langobardorum to be read as providential history, the fact that he seems not to have completed his work means that its purpose - like that of the Fredegar chronicle - is unclear. The model Paul takes, however, is unquestionably that of Jordanes, though he begins not with the continents of the world, but more specifically with Germania, before turning to Scandinavia, and he announces that his source is Pliny, rather than Orosius. ${ }^{54}$ The Romana departs more radically from the model of Jordanes: whereas the Roman History of Jordanes begins with Eusebius/Jerome, Paul's Romana takes as his point of departure the Breviarium of Eutropius - a highly abbreviated narrative of Roman history written in the mid-fourth century. Essentially Paul provides six very short books to follow on from Eutropius' ten, bringing the narrative from 364 down to the days of Justinian. In fact he also adds some preliminary material to Eutropius' work, for while the latter starts with the foundation of Rome, the former looks back earlier to the days of Janus. Not that Paul was the only historian to insert classical mythology into synchronising history, ${ }^{55}$ and indeed we have already noted the importance of the Troy story, which

49 Dörler, The Liber Historiae Francorum, 25.

50 Goffart, The Narrators of Barbarian History, 3.

51 Jordanes, Historia Romana.

52 Jordanes, Historia Getica, I 4-V 38, ed. Mommsen, 54-64; Merrills, History and Geography, 115-132.

53 Goffart, The Narrators of Barbarian History, 68-84.

54 Paul the Deacon, Historia Langobardorum, I, 1-2, ed. Waitz, 52-53.

55 Whitby, The Biblical Past in John Malalas, 289-290. 
is present, for instance, in Eusebius/Jerome, Fredegar and the Liber Historiae Francorum. Despite this apparent interest in the mythical pagan past, Paul also inserts Christian material into Eutropius' account. In the preface he reveals that Adelperga, the wife of Arichis II of Benevento, had complained to him that Eutropius' work failed to mention the history of Christianity. ${ }^{56}$ As a result he added material from Jerome and Orosius to his base text.

We find a similar mixture of religious and secular history in the very much longer work by Bishop Frechulf of Lisieux in c. 829. This was published in Migne's Patrologia Latina under the title Chronicorum Tomi Duo, though in the most recent edition it is presented as Historiarum Libri XII (rather in the manner of Gregory of Tours' Histories). ${ }^{57}$ Certainly the term schronicles, as defined by Cassiodorus, is inappropriate: Frechulf's historical work is not short, but it is universal. Whether or not it was originally described as a chronicle, it follows the outline and much of the chronology of Eusebius/Jerome. Its first half provides an account of the known world from the Creation to Augustus, in which Biblical, Trojan, Greek and Roman history is neatly combined. The second half runs from Augustus down to the early seventh century, and while for much of the narrative it is concerned with the Roman Empire, combining Roman and Church History, including Rufinus, Orosius, and the Historia Tripartita of Cassiodorus, in its closing stages it deals with the Franks, the Lombards, and the Papacy as well as the Byzantines.

The titles of the historical works written by Jordanes and Paul make clear their focus on specific peoples: they can scarcely be called universal histories. The same is certainly true of the two major historical works written by Isidore and Bede. The bishop of Seville's De origine Gothorum begins with praise of Spain (the Laus Spaniae), before turning to the Goths themselves, who are given a biblical starting point, with Gog and Magog: thereafter Isidore sets their early history in a Roman context, dealing with Julius Caesar and Pompey, Valerian and Gallienus, Constantine, and Valens, largely in the words of Jerome and Orosius, before concentrating on the arrival of the Goths in the Roman world, and their settlement in Spain..$^{58}$ While Isidore begins firmly in Spain, Bede begins his Historia Ecclesiastica Gentis Anglorum with a description of Britain, very much in the Orosian mode, before turning to the invasions of Julius Caesar and Claudius, followed by an account of British history, concentrating largely on episodes involving the coming of Christianity, the persecution of Christians, and the presence of heresy, down to the arrival of the Anglo-Saxons. ${ }^{59}$ Thereafter the history concentrates on the English, and more especially on the English Church.

But while Isidore and Bede wrote histories about the Goths and the Anglo-Saxons (and indeed Bede also wrote a history of the abbots of his own monastery of Wearmouth-Jarrow), ${ }^{60}$ they also wrote chronicles, which return us closer to our point of departure. Isidore's Chronicle survives in two versions, the first running to 615/6, the second to 626 , both of which begin, as does the Chronicle of Prosper, with an abridgement of Eusebius/Jerome. ${ }^{61}$ It is not, however, simply an epitome of the earlier work, with additions. On certain issues it

56 Paul the Deacon, Historia Romana, ep. to Adelperga, ed. Droysen, 4-5. On other writings from the court of Arichis see Wood, Giovardi, MS Verolensis 1, Arichis and Mercurius.

57 Frechulf, Historiarum Libri XII.

58 Isidore, Historia Gothorum, Wandalorum, Sueborum, ed. Mommsen, 267-276; Merrills, History and Geography, 185-205; Wood, Politics of Identity, 72-74.

59 Bede, Historia Ecclesiastica Gentis Anglorum, I, 1-12, ed. Colgrave and Mynors, 14-45; Merrills, History and Geography, 249-273.

60 Bede, Historia Abbatum, ed. Grocock and Wood.

61 Wood, Politics of Identity, 70-72; Burgess and Kulikowski, Mosaics of Time, 32, 199. 
promotes a particular message - for instance its hostility towards the Jews is evident in its use of material drawn from Rufinus of Aquileia, and from the Historia Tripartita, the ecclesiastical history of Cassiodorus/Epiphanius. ${ }^{62}$ More dramatically, it recasts the information contained in Jerome's Chronicle within Augustine's concept of the Six Ages of the World, ${ }^{63}$ itself derived from Hippolytus' reading of the Book of Daniel, thus very obviously enhancing the providential nature of the narrative. ${ }^{64}$ After the prefatory material the first entry simply states Prima aetas saeculi.

Isidore's understanding of the chronicle form, however, is yet more apparent from a much shorter chronicle text which is to be found in Book V of the Bishop of Seville's Etymologies. Here the history of the world is reduced to 137 entries, with 10 allotted to the First Age, from Adam to the Flood; 9 to the Second, from the Flood to Abraham: 10 from Abraham to David: 20 from David to the destruction of the Temple in Jerusalem: 23 from the Babylonian Captivity to the Birth of Christ: and a much fuller, though still sketchy, 55 entries covering the period from the Incarnation to the time of writing $(627 / 8 \mathrm{AD})$, with the last entry devoted to the conversion of the Jews by King Sisebut (dated to 615/6). ${ }^{65}$

The meaning of this so-called Lesser Chronicle, however, is not just indicated by the entries included in it. The short text is the culmination of a series of chapters in the Etymologies, beginning with one entitled De chronicae vocabulo: the term "chronicle«, which the author notes is derived from the Greek xoóvos. ${ }^{66}$ Isidore then deals with the divisions of time (moments and hours, days, the night, the week, months, solstices and equinoxes, seasons, years, Olympiads, lustrums and jubilees, periods and ages) before giving his description of times (De descriptione temporum), which is how he entitles his short chronicle. The little collection of chronological information that follows is, thus, an illustration of the division of time, and above all its division into Six Ages, which are broken down into smaller units defined by dates from the Creation, the lifetimes of leading figures of the Old Testament and subsequently the regnal years of kings and emperors. In so far as there is a narrative over and above that implied by the dating clauses, it is concerned largely with religious matters, derived from the Bible or relating to the history of the Church, and especially heresy and its extirpation.

Bede's chronicles have much in common with those of Isidore. Like that contained within the Etymologies, they are to be found in longer, non-historical, works. The earliest of Bede's chronicles, the so-called Chronica Minora, constitutes chapters 16-22 of the De Temporibus, written in c.703: the first of his two treatises on time. This takes the chapters on time to be found in the Etymologies as its starting point, repeating much of what Isidore has to say of the various chronological divisions. Yet having dealt with years Bede does not continue with Olympiads, lustrums and jubilees (such classical divisions were obviously no longer of use), but instead he turns to the lunar cycle, and thence to the Easter cycle. ${ }^{67}$

Easter Tables had long been associated with other chronological material, as we have already seen in the Chronography of 354. Isidore had not dealt with them in his chronological discussions, reserving his chapter on the Easter Cycle for the following book of the

62 Wood, Politics of Identity, 206; Burgess and Kulikowski, Mosaics of Time, 199.

63 Burgess and Kulikowski, Mosaics of Time, 199.

64 Augustine, De catechizandis rudibus, 22; Darby, Bede and the End of Time, 22; Wood, Politics of Identity, 122; Burgess and Kulikowski, Mosaics of Time, 199.

65 Isidore, Etymologiae, ed. Lindsay, V 39, trans. Barney et al., 130-133.

66 Isidore, Etymologiae, V 28-39, trans. Barney et al., 125-33.

67 Bede, De Temporibus, ed. Jones: trans. Kendall and Wallis. 
Etymologies, which includes a discussion of ecclesiastical offices. However, earlier chronographers and chroniclers, including Hippolytus, Pannadorus, Annianus, and, above all, the author of the aptly named Chronicon Paschale, had wrestled with the date of Easter. ${ }^{68}$ Bede's own interest in the correct dating of the Paschal Feast had a particular context in the conflicts engendered in the British Isles in the course of the seventh and eighth centuries. But for him the Easter Cycle not only raised the question of the calculation of the date on which the Feast should be celebrated, but also, and more importantly, the matter of its symbolism. The question of the Paschal Cycle thus becomes a major issue in Bede's discussion of time. Easter is intended to echo the transition of Death to Life: it must reflect the conquest of the Dark by the True Light, and must therefore follow the equinox: it must come in the third week of the moon, since it occurred in the third period of the world, the first and second being before and after the Law, as defined by the giving of the Ten Commandments, and the third being the Age of Grace. Bede's chronicle account of the Six Ages then follows, offering another way of dividing up time. Being largely derived from Isidore, this continues the Bishop of Seville's interest in the Church and heresy, adding some information, both on religious matters, and relating to the arrival in England and the conversion of the Anglo-Saxons. Bede also opts for a different calculation of the date of the Incarnation, following Jerome's Vulgate, whereas Isidore had followed the Septuagint - a choice that would earn him an accusation of heresy, to which he replied in the Letter to Pleguin. ${ }^{69}$ The Chronicle ends with the statement that 'the rest of the Sixth Age is known to God alone.' Bede is thus careful to make it clear that he is making no millennarian prediction, although he is clearly aware that the End of Time could be imminent.

The criticism raised against the De Temporibus was no doubt one of the reasons for Bede revisiting the subject in his later and yet more substantial work, the De temporum ratione of 725. Here also the calculation of Easter is a central concern, and once again the discussion of the Paschal Cycle immediately precedes Bede's account of the Six Ages, which constitutes chapter $66 . .^{70}$ This longer chronicle largely follows Jerome, albeit with numerous biblical additions, together with information from Eutropius, Rufinus, Orosius, Gildas, Prosper, Marcellinus, Isidore, and above all in its most recent section the Liber Pontificalis. Its final entry, dealing with a Saracen siege of Constantinople, their subsequent war with the Bulgars, and the translation of the bones of Augustine of Hippo from Sardinia to Pavia, is a neat illustration of the extent to which, unlike the Historia Ecclesiastica Gentis Anglorum, this is concerned with the known world, and its existence through all time.

Isidore and Bede, thus, point us back to the notion of the chronicle as one way among several of conceiving of time. They also suggest that, while for the modern historian trying to recreate the past events and dates are what matters, for the late-antique and early-medieval author the chief concern was different. Even a historian who is regarded as an honorary modern, like Bede, has a very different concept of the vera lex historiae than we have now. ${ }^{71}$ Although individual chronicles have political, moral and doctrinal agendas, the record of the passing of time was an end in itself, because, for the Christian, it afforded the possibility of rare glimpses of the workings of providence. Time in Late Antiquity and the Early Middle

68 Whitby, The Biblical Past in John Malalas, 280, 283, 284, 293, 294, 301, 302.

69 Bede, Epistola ad Plegvinam; Burgess and Kulikowski, Mosaics of Time, 205.

70 Bede, De Temporum Ratione, 66, ed. Jones, 463-535, trans. Wallis, 157-237.

71 Ray, Bede's Vera Lex Historiae. 
Ages, as in many societies, ${ }^{72}$ had religious as well as historical connotations. Chronicles that began with the Creation, the Birth of Adam, the Flood, or the Birth of Abraham, were inevitably concerned to some extent with the history of the known world, even if, increasingly, an author's knowledge or interest became confined to the area he knew well: they also had a sense of the workings of divine providence, not least if they combined the Augustinian reading of the Six Ages with the chronological record of Eusebius/Jerome. But so too histories, even histories of individual peoples, might have a similar concern with providence, despite their provincial focus. There are no clear distinctions to be made when one considers what constitutes a chronicle and what constitutes a history, and whether or not either was universal. 


\section{References}

Augustine, De Catechizandis Rudibus, ed. Michael Petrus Josephus van den Hout, Aurelii Augustini Opera, 13, 2, Corpus Christianorum Series Latinorum 46 (Turnhout, 1969).

Bede, De Temporibus, ed. C.W. Jones, Beda Opera Didascalica, Corpus Christianorum, Scriptores Latinorum 123C (Turnhout, 1977) 585-611: trans. Calvin B. Kendall and Faith Wallis, Bede. On the Nature of Things and On Times (Liverpool, 2010) 106-31.

Bede, De Temporum Ratione, ed. Charles W. Jones, Beda Opera Didascalica, Corpus Christianorum, Scriptores Latinorum 123B (Turnhout 1977) 263-544: trans. Faith Wallis, Bede: The Reckoning of Time (Liverpool 1999).

Bede, Epistola ad Plegvinam, ed. Charles W. Jones, Beda Opera Didascalica, Corpus Christianorum, Scriptores Latinorum 123C (Turnhout, 1977) 617-26.

Bede, Historia Abbatum, ed. Chris Grocock and Ian N. Wood, Abbots of Wearmouth and Jarrow (Oxford, 2013).

Bede, Historia Ecclesiastica Gentis Anglorum, ed. Bertram Colgrave and Roger Aubrey Baskerville Mynors (Oxford, 1969).

Burgess, Richard, W., Hydatius and the Final Frontier: the Fall of the Roman Empire, in: Ralph W. Mathisen and Hagith S. Sivan (eds.), Shifting Frontiers in Late Antiquity (Aldershot, 1996) 321-332.

Burgess, Richard, W. and Kulikowski, Michael, Mosaics of Time: the Latin Chronicle Traditions from the First Century BC to the Sixth Century AD, vol. 1, A Historical Introduction to the Chronicle Genre from its origins to the High Middle Ages (Turnhout, 2013).

Cassiodorus, Institutiones divinarum et saecularium litterarum, ed. Roger Aubrey Baskerville Mynors (Oxford, 1937): trans. James W. Halporn and Mark Vessey, Cassiodorus. Institutions and Divine and Secular Learning (Liverpool, 2004).

Collins, Roger, Die Fredegar-Chroniken, MGH, Studien und Texte 44 (Hannover, 2007).

Darby, Peter, Bede and the End of Time (Farnham, 2012).

Dörler, Philipp, The Liber Historiae Francorum - a model for a new Frankish self-confidence, Networks and Neighbours 1 (2013) 26-43. Retrieved on 12 June 2015 from http://www. networksandneighbours.org/index.php/n/article/view/34/15.

Frechulf, Historia Libri XII, ed. Michael I. Allen, Corpus Christianorum, Continuatio Medievalis 169-169A (Turnhout, 2002).

Fredegar, ed. Bruno Krusch, MGH, SRM 2 (Hannover, 1888).

Goffart, Walter, From Historiae to Historia Francorum and Back Again. Aspects of the Textual History of Gregory of Tours, in: Thomas F. X. Noble and John J. Contreni (eds.), Religion, Culture, and Society in the early Middle Ages: Studies in Honour of Richard E. Sullivan (Kalamazoo, 1987), 55-76.

Goffart, Walter, The Narrators of Barbarian History. Jordanes, Gregory of Tours, Bede, and Paul the Deacon (Princeton, 1988).

Gregory of Tours, Decem Libri Historiarum, ed. Bruno Krusch, MGH, SRM I, 1 (Hannover, 1950): trans. L. Thorpe, Gregory of Tours. The History of the Franks (London 1974).

Hieronymus, Chronicon, ed. Rudolf Helm, Eusebius Werke, Bd. 7 (Berlin, 1956).

Higham, Nicholas, J., King Arthur. Myth-Making and History (London, 2002).

Historia Brittonum, ed. John Morris, Nennius. Arthurian Period Sources, vol. 8 (London, 1980). Isidore, Chronica Maiora, ed. Theodor Mommsen, MGH, AA XI (Berlin, 1894).

Isidore, Historia Gothorum, Wandalorum, Sueborum, ed. Theodor Mommsen, MGH, AA XI (Berlin, 1894). 
Isidore, Etymologiarum sive Originum Libri XX, ed. Wallace M. Lindsay (Oxford 1911): trans. Stephen A. Barney, W. J. Lewis, J. A. Beach, Oliver Berghof, The Etymologies of Isidore of Seville (Cambridge, 2006).

Jordanes, Romana et Getica, ed. Theodor Mommsen, MGH, AA V 1 (Berlin, 1882).

Liber Historiae Francorum, ed. Bruno Krusch, MGH, SRM II (Hannover, 1888).

Lozovsky, Natalia, »The Earth is our Book«. Geographical Knowledge in the Latin West ca. 40o1000 (Ann Arbor, 2000).

Merrills, Andrew H., History and Geography in Late Antiquity (Cambridge, 2005).

Muhlberger, Steven, The Fifth-Century Chroniclers: Prosper, Hydatius and the Gallic Chronicler of 452 (Leeds, 1990).

Orosius, Historia Adversus Paganos, ed. Marie-Pierre Arnaud-Lindet, Orose, Histoires contre les Païens, 3 vols. (Paris, 2003): trans. Andrew T. Fear, Orosius, Seven Books against the Pagans (Liverpool, 2010).

Paul the Deacon, Historia Langobardorum, ed. Georg Waitz, MGH, SRG in usum scholarum (Hannover, 1878).

Paul the Deacon, Historia Romana, ed. Hans Droysen, MGH, AA II (Berlin, 1879).

Ray, Roger, Bede's Vera Lex Historiae, Speculum 55 (1980) 1-21.

Salzman, Michael Renee, On Roman Time. The Codex-Calendar of 354 and the Rhythms of Urban Life in Late Antiquity (Berkeley, 1990).

Van Nuffelen, Peter, Orosius and the Rhetoric of History (Oxford, 2012).

Wallace-Hadrill, John Michel, trans. and ed., The Fourth Book of the Chronicle of Fredegar (London, 1960).

Whitby, Mary, The Biblical Past in John Malalas and the Paschal Chronicle, in: Amirav and B. ter Haar Romeny (eds.), From Rome to Constantinople: Studies in Honour of Averil Cameron (Leuven, 2007) 279-302.

Wood, Ian N., The End of Roman Britain: Continental Evidence and Parallels, in: Michael Lapidge and David N. Dumville (eds.), Gildas: New Approaches (Woodbridge, 1984) 1-25.

Wood, Ian N., Fredegar's Fables, in: Anton Scharer and Georg Scheibelreiter (eds.) Historiographie im frühen Mittelalter (Vienna, 1994) 359-66.

Wood, Ian N., The Priest, the Temple and the Moon in the Eighth Century, Brixworth Lecture (Leicester, 2008).

Wood, Ian N., Chains of Chronicles: the Example of London, British Library ms. Add. 16974, in: Richard Corradini, Max Diesenberger and Meta Niederkorn-Bruck (eds.), Zwischen Niederschrift und Wiederschrift. Frühmittelalterliche Hagiographie und Historiographie im Spannungsfeld von Kompendienüberlieferung und Editionstechnik (Vienna, 2010) 67-77.

Wood, Ian N., Giovardi, MS Verolensis 1, Arichis and Mercurius, in: Richard Corradini, Max Diesenberger and Meta Niederkorn-Bruck (eds.), Zwischen Niederschrift und Wiederschrift. Frühmittelalterliche Hagiographie und Historiographie im Spannungsfeld von Kompendienüberlieferung und Editionstechnik, Forschungen zur Geschichte des Mittelalters 18 (Vienna, 2010) 197-210.

Wood, Jamie, The Politics of Identity in Visigothic Spain. Religion and Power in the Histories of Isidore of Seville (Leiden, 2012). 